\title{
MODEL PEMBENTUKAN MINDSET KEWIRAUSAHAAN BAGI GENERASI Z PADA SISWA SMK PELITA NUSANTARA I SEMARANG
}

\author{
Widaryanti ${ }^{*}$ \\ Luhgiatno $^{2}$ \\ Lilies Sri Sumarsih ${ }^{3}$ \\ 1,2 Sekolah Tinggi Ilmu Ekonomi Pelita Nusantara, Semarang, Indonesia \\ ${ }^{3}$ SMK Pelita Nusantara I, Semarang, Indonesia \\ $\underline{\text { wdr.yanti@gmail.com }}^{\left.1^{*}\right)}$ \\ luhgiatno-smg@yahoo.com ${ }^{2}$ \\ wdr.yanti@gmail.com ${ }^{3}$
}

\author{
Kata Kunci: \\ [Mindset, \\ Kewirausahaan, \\ Generasi Z, Siswa, \\ Entrepreneur]
}

\begin{abstract}
Abstrak: Sebagian besar masyarakat Indonesia mempunyai anggapan bahwa tujuan sekolah adalah untuk bekerja bukan untuk menjadi seorang wirausaha. Minat untuk menjadi seorang wirausaha (entrepreneur) masih menjadi alternative terakhir untuk sebagian besar masyarakat Indonesia. Karir sebagai wirausaha (entrepreneur) bukanlah pilihan yang menarik khususnya bagi generasi muda. Mindset kewirausahaan ialah pola pikir seseorang yang berorientasi entrepreneur. Mindset kewirausahaan harus dibangun dikalangan generasi Z. Sehingga diperlukan pelatihan model pembentukan mindset kewirausahaan bagi generasi Z pada siswa SMK Pelita Nusantara I Semarang. Peserta pelatihan yaitu siswa siswi kelas X, XI dan XII yang telah melakukan rintisan usaha. Pelatihan telah diadakan pada bulan Agustus 2021 dengan mengangkat tema tentang membangun mindset wirausaha bagi generasi Z di SMK Pelita Nusantara I Semarang. Hasil dari pengabdian masyarakat ini adalah telah terjadi perubahan mindset, pengetahuan dan kemampuan siswa-siswi SMK Pelita Nusantara Semarang dalam kewirausahaan. Hal ini akan berpengaruh pula terhadap daya pandang, omzet penjualan usaha dari siswa-siswi SMK Pelita Nusantara I, akibatnya pendapatan akan meningkat dan laba usaha mereka juga akan naik.
\end{abstract}

Published by:

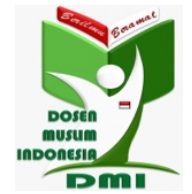

Copyright (C) 2021 The Author(s)

This article is licensed under CC BY 4.0 License

$(\text { (c) })_{\text {EY }}$

https://dmi-journals.org/jai 


\section{Pendahuluan}

Pengangguran di Indonesia terjadi dikarenakan lapangan pekerjaan lebih sedikit jika dibandingkan dengan jumlah pencari kerja. Indonesia merupakan salah satu negara berkembang yang mempunyai tingkat pengangguran yang tinggi. Menurut data Badan Pusat Statistik (BPS) Agustus 2020, terdapat 128.454.180 orang $(92,93)$ penduduk Indonesia yang bekerja. Pada tahun 2019 bulan Agustus jumlah penduduk Indonesia yang bekerja sebanyak 128.755 .270 orang $(94,77 \%)$. Dari data ini dapat diketahui bahwa terjadi penurunan jumlah penduduk Indonesia yang bekerja dari tahun 2019 ke tahun 2020. Data pengangguran pada bulan Agustus 2019 sebanyak 7.104 .420 orang (5,23\%), sedangkan jumlah pengangguran pada Agustus tahun 2020 sebanyak 9.767.750 orang $(7,07 \%)$. Dari data pengangguran ini dapat kita ketahui bahwa telah terjadi penambahan pengangguran selama tahun 2019 ke tahun 2020 (Salsabila \& Handayani, 2021).

Dilihat dari tingkat pendidikan, tingkat pengangguran terbuka berasal dari lulusan Sekolah Menengah Kejuruan (SMK) masih yang paling tinggi diantara tingkat pendidikan lain, yaitu sebesar 8,49 persen. Tingkat pengangguran terbuka (TPT) ialah adalah persentase jumlah pengangguran terhadap jumlah angkatan kerja. Berdasarkan tingkat pendidikan pada bulan Februari 2021 pengangguran tidak/belum pernah sekolah sebanyak 20.461 orang, tidak/belum tamat SD sebanyak 342.734 orang. Pengangguran lulusan SD sebanyak 1.219.494 orang, lulusan SLTP sebanyak 1.515.089 orang, lulusan SLTA sebanyak 2.305.093 orang, lulusan SMK sebanyak 2.089.137 orang, lulusan akademi/diploma sebanyak 254.457 orang dan lulusan universitas sebanyak 999.543 orang. Dari data diatas dapat dilihat bahwa pengangguran intelektual di Indonesia semakin meningkat. Hal ini dikarenakan kesempatan yang ada belum mampu menyerap semua lulusan baik tingkat SMA, SMK, diploma maupun sarjana (Semarang, 2020).

Berdasarkan data BPS 2020, lulusan SMA dan SMK masih banyak yang menganggur, maka perlu adanya perombakan terhadap paradigma dan kurikulum di SMA maupun SMK. Perombakan paradigm ini diharapkan SMA atau SMK dapat melakukan perencanaan untuk mengarahkan produktivitas sumber daya manusia sehingga lulusan SMA dan SMK siap kerja dan jadi pencipta usaha bukan sebagai pencari kerja. Kualitas sumber daya manusia lulusan SMA maupun SMK yang dibutuhkan adalah lulusan yang mempunyai pengetahuan dan ketrampilan yang tinggi serta sikap mental yang tangguh terutama sikap mental kewirausahaan (Santoso \& Almadana, 2021).

Masalah utama pendidikan kewirausahaan tingkat SMA atau SMK adalah karena pola pikir (mindset), sikap (attitude), keterampilan (skill) maupun pengetahuan (knowledge) (Indartono, Ph.D, 2015). Sebagian besar masyarakat Indonesia mempunyai anggapan bahwa tujuan sekolah adalah untuk bekerja bukan untuk menjadi seorang wirausaha. Minat untuk menjadi seorang wirausaha (entrepreneur) masih menjadi alternative terakhir untuk sebagian besar masyarakat Indonesia. Karir sebagai wirausaha (entrepreneur) bukanlah pilihan yang menarik khususnya bagi generasi muda (Thrikawala, 2011).

Kewirausahaan sudah lama diperkenalkan kepada masyarakat Indonesia, namun banyak masyarakat yang belum memiliki kecakapan dalam menciptakan lapangan kerja minimal bagi mereka sendiri (Indriyatni, 2013). Pencari pekerjaan jauh lebih tinggi jika dibandingkan dengan orang-orang yang membuka lapangan kerja. Tidak jauh beda dengan siswa lulusan SMK. Mereka setelah meluluskan studinya akan lebih menyukai mencari pekerjaan jika dibandingkan membuka lapangan kerja. Alasan siswa lebih 
menyukai mencari pekerjaan karena menjadi wirausaha (entrepreneur dianggap sebagai pilihan yang mempunyai risiko tinggi jika dibandingkan jika bekerja di perusahaan (Kasnelly, 2020). Alasan lainnya karena diperlukan modal yang cukup untuk memulai suatu usaha serta pendapatan yang masuk tidak pasti masih membuat siswa lebih memilih bekerja di suatu perusahaan (Wibowo \& Nulhaqim, 2015).

Padahal sebagai seorang entrepreneur, mindset seperti itu harus dihilangkan. (McMillan et al., 2012) menyatakan bahwa mindset kewirausahaan ialah pola pikir seseorang yang berorientasi entrepreneur. Seorang entrepreneur lebih memilih menjalani ketidakpastian daripada menghindari, melihat segala sesuatu lebih sederhana daripada orang lain yang melihatnya secara kompleks. Selain itu seorang entrepreneur mau belajar sesuatu yang baru dan merupakan seorang pengambil risiko. Berdasarkan latar belakang uraian diatas perlu dibuat model pembentukan mindset kewirausahaan bagi generasi Z pada siswa SMK Pelita Nusantara I Semarang.

\section{Metode Pelaksanaan}

Kegiatan ini merupakan rangkaian kegiatan pengabdian kepada masyarakat yang diselenggarakan atas kerjasama antara STIE Pelita Nusantara dengan SMK Pelita Nusantara I. Pengabdian masyarakat pengabdian masyarakat ini berlangsung untuk mendampingi SMK Pelita Nusantara dalam membentuk mindset kewirausahaan bagi siswa-siswinya. Pelaksanaan pelatihan pembentukan mindset kewirausahaan dan digital marketing dilakukan di Semarang pada tanggal Rabu, 22 September 2021. Dalam pengabdian masyarakat ini yang menjadi mitra pengabdian masyarakat adalah SMK Pelita Nusantara I. SMK Pelita Nusantara I merupakan salah satu sekolah pencetak wirausaha di Kota Semarang.

Pelaksanaan pengabdian masyarakat ini dimulai dari tahap persiapan, pelaksanaan dan pasca pelaksanaan. Tahap Persiapan, meliputi kegiatan perijinan kepada pihak terkait tentang pelaksanaan pengabdian masyarakat ini. Selain perijinan, juga disiapkan jadwal kegiatan selama pengabdian masyarakat dan pembagian tugas tim pengabdian masyarakat STIE Pelita Nusantara.

Tahap Pelaksanaan, akan dilaksanakan pelatihan motivasi agar siswa-siswi aktiv dalam program pengabdian msyarakat ini, Pelatihan pembentukan mindset kewirausahaan dan pembuatan digital marketing yang menarik. Program pendampingan berlangsung di SMK Pelita Nusantara I.

Tahap Pasca Pelaksanaan, berupa evaluasi kegiatan dengan memberikan kuesioner kepada peserta pendampingan. Peserta diberikan pertanyaan seputar perubahan mindset berwirausaha serta manfaat digital marketing pada usaha rintisan mereka.

\section{Hasil dan Pembahasan}

Pengabdian masyarakat telah dilaksanakan di Sekolah Menengah Kejuruan Pelita Nusantara I. Pendampingan terhadap siswa-siswa SMK Pelita Nusantara I dilakukan salah satunya dengan memberikan pelatihan bagi semua peserta. Peserta pelatihan yaitu siswa siswi kelas X, XI dan XII yang telah melakukan rintisan usaha. Pelatihan telah diadakan pada bulan Agustus 2021 dengan mengangkat tema tentang membangun mindset wirausaha bagi generasi Z di SMK Pelita Nusantara I Semarang. 
Pendampingan dilakukan oleh tim pengabdian masyarakat STIE Pelita Nusantara. Pendampingan dilakukan dengan memberi masukan dan solusi seputar permasalahan yang dihadapi SMK Pelita Nusantara I dalam mengembangkan mindset wirausaha bagi siswa siswinya. Tolok ukur keberhasilan program pengabdian masyarakat ini adalah berubahnya mindset kewirausahaan siswa-siswi SMK Pelita Nusantara I sehingga mampu melaksanakan rintisan usaha dan mampu membuat proposal pendanaan rintisan usaha. Jenis-jenis usaha yang telah dimiliki oleh siswa-siswi SMK Pelita Nusantara yang mengikuti pelatihan antara lain produk peternakan (burung), penjualan online kosmetik, makanan ringan (snack), fashion dll.

Kegiatan-kegiatan yang dilakukan antara lain yaitu pelatihan pembentukan mindset kewirausahaan bagi siswa-siswi SMK Pelita Nusantara I. Pelatihan pembentukan mindset kewirausahaan dilakukan dengan narasumber dari pengajar-pengajar STIE Pelita Nusantara yang pakar dibidang kewirausaan. Pelatihan tentang digital marketing juga telah diajarkan kepada peserta pelatihan. Perkembangan internet saat ini mampu mempengaruhi dunia marketing, bahkan sekarang digital marketing dianggap sebagai trendsetter. Pemanfaatan internet untuk digital marketing mulai popular sehingga diperlukan konten-konten pemasaran untuk diupload ke facebook atau Instagram yang menarik dan bervariasi sehingga dapat mempengaruhi minat konsumen untuk membeli. Strategi pemasaran digital harus diterapkan melalui akun social media peserta pelatihan diantaranya facebook dan Instagram masing-masing peserta pelatihan.

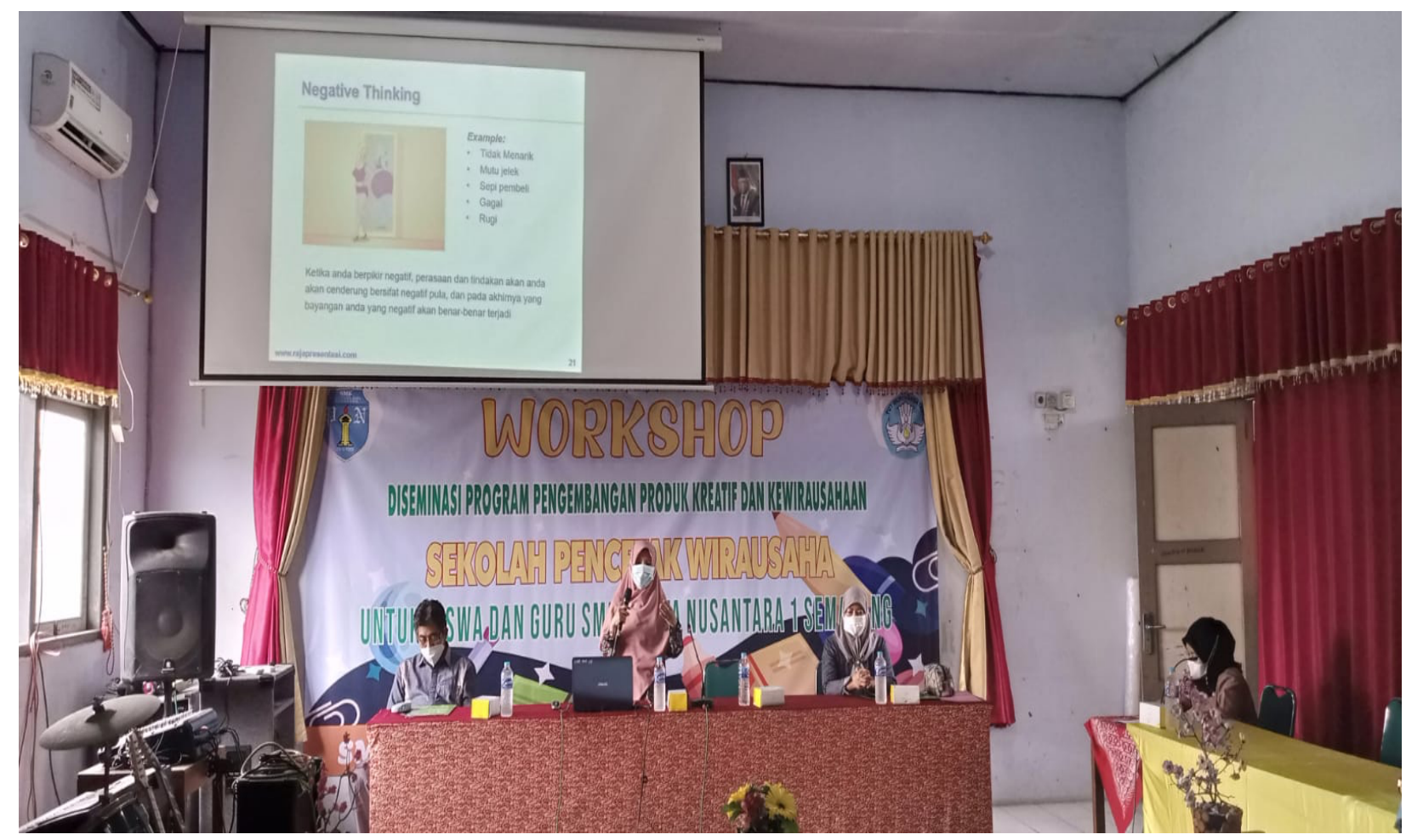

Gambar 1. Pelatihan Pembentukan Mindset Kewirausahaan 


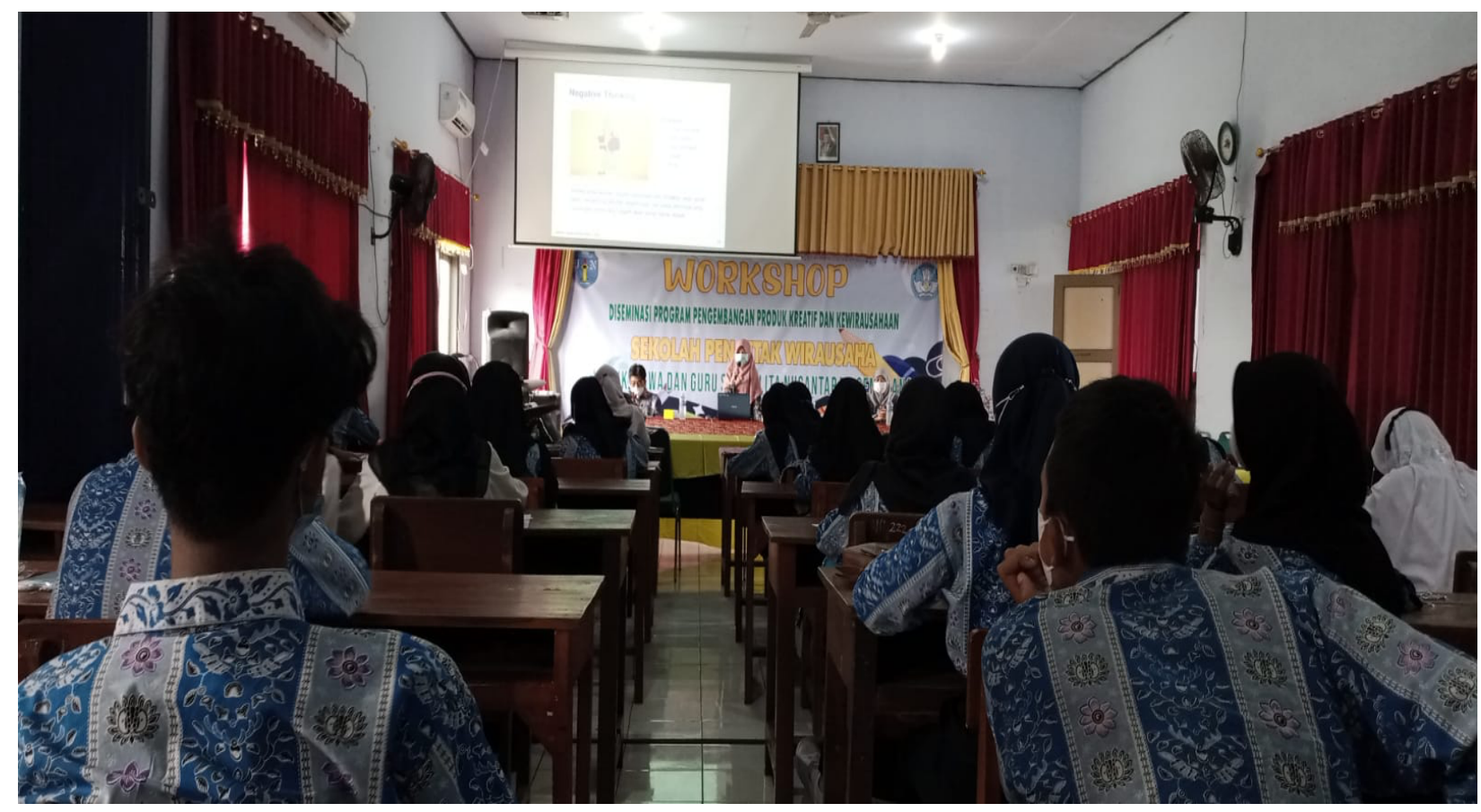

Gambar 2. Pelatihan Digital Marketing

Kegiatan pengabdian masyarakat ini menghasilkan peningkatan pengetahuan dan kemampuan siswa-siswi SMK Pelita Nusantara Semarang dalam pemasaran menggunakan digital marketing. Hal ini akan berpengaruh pula terhadap omzet penjualan usaha dari siswa-siswi SMK Pelita Nusantara I akan meningkat, akibatnya pendapatan akan meningkat dan laba juga akan naik. Hal ini didukung hasil penelitian (Helmalia \& Afrinawati, 2018) yang memberikan bukti bahwa e-commerce mempunyai pengaruh positif signifikan terhadap pendapatan UMKM.

\section{Kesimpulan}

Pelatihan Program Kemitraan Masyarakat pengabdian masyarakat yang dilakukan oleh tim pengabdian masyarakat dari STIE Pelita Nusantara bekerjasama dengan SMK Pelita Nusantara I Semarang ini sangat bermanfaat dan sangat membantu bagi pembentukan mindset kewirausahaan siswa-siswi SMK Pelita Nusantara I. Peserta pelatihan dapat mengembangkan usahanya hal ini terlihat dari semangat dan antusiasme siswa-siswi SMK Pelita Nusantara I dalam mengikuti pelatihan pembuatan perubahan mindset kewirausahaan dan pelatihan digital marketing. Peserta pelatihan akan melakukan digital marketing untuk pemasaran produk-produknya.

\section{Ucapan Terimakasih}

Ucapan terima kasih disampaikan kepada Ketua STIE Pelita Nusantara Semarang, Kepala SMK Pelita Nusantara I sebagai mitra pengabdian masyarakat, serta pihak-pihak yang ikut membantu pelaksanaan pengabdian masyarakat ini.

\section{Referensi}

Helmalia, H., \& Afrinawati, A. (2018). Pengaruh e-commerce terhadap peningkatan pendapatan usaha mikro kecil dan menengah di Kota Padang. JEBI (Jurnal Ekonomi Dan Bisnis Islam), 3(2), 237-246. 
Indartono, Ph.D, S. (2015). B_8 Model Pembentukan Mind-Set,Attitude, Skills, dan Knowledge (MASK) dalam Penyiapan Sarjana IPA yang Berjiwa Entreupreneur.pdf. http://staffnew.uny.ac.id/upload/131666730/penelitian/B_8 Model Pembentukan Mind-Set,Attitude, Skills, dan Knowledge (MASK) dalam Penyiapan Sarjana IPA yang Berjiwa Entreupreneur.pdf

Indriyatni, L. (2013). Dalam Menumbuhkan Minat Mahasiswa Untuk Berwirausaha (Studi Kasus pada Mahasiswa STIE PELITA NUSANTARA SEMARANG ) Lies Indriyatni *). Fokus Ekonomi, 8(1), 52-59.

Kasnelly, F. A. J. S. (2020). Meningkatnya Angka Pengangguran Ditengah Pandemi (Covid19). Al-Mizan: Jurnal Ekonomi Syariah, 3(1), 45-60.

McMillan, D. J., Walsh, G., Gray, C., Hanna, K., Carville, S., \& McCracken, O. (2012). Changing mindsets: the benefits of implementing a professional development model in early childhood settings in Ireland. Professional Development in Education, 38(3), 395410.

Salsabila, A. H., \& Handayani, H. R. (2021). Pengaruh Faktor Sosial Ekonomi Terhadap Keputusan Penduduk Lanjut Usia Untuk Bekerja (Studi Kasus Kota Semarang). Diponegoro Journal of Economics, 9(2), 91-104.

Santoso, T. A., \& Almadana, A. V. (2021). Pengaruh Pendidikan Kewirausahaan dan Efikasi Diri terhadap Minat Berwirausaha Siswa SMK di Kota Semarang. ECONBANK: Journal of Economics and Banking, 3(1), 19-26.

Semarang, B. P. S. K. (2020). Kecamatan Tembalang Dalam Angka 2019. Semarang: BPS Kota Semarang.

Thrikawala, S. (2011). The determinants of entrepreneurial intention among academics in Sri Lanka. International Proceedings of Economics Development \& Research, 4, p454-468.

Wibowo, H., \& Nulhaqim, S. A. (2015). Kewirausahaan Sosial (Merevolusi Pola Pikir Menginisiasi Mitra Pembangunan). In Program Manager. 